\title{
Role of Accumulated Calcium in Alleviating Aluminum Injury in Wheat Plants
}

\author{
M. Alamgir Hossain, ${ }^{1,2}$ M. Ashrafuzzaman, ${ }^{1,2}$ A. K. M. Zakir Hossain, ${ }^{1,3}$ \\ Mohd. Razi Ismail, ${ }^{2}$ and H. Koyama ${ }^{3}$ \\ ${ }^{1}$ Department of Crop Botany, Bangladesh Agricultural University, Mymensingh 2202, Bangladesh \\ ${ }^{2}$ Institute of Tropical Agriculture, Universiti Putra Malaysia (UPM), 43400 Serdang, Selangor, Malaysia \\ ${ }^{3}$ Laboratory of Cell Technology, Gifu University, Japan
}

Correspondence should be addressed to M. Ashrafuzzaman; drashraf2007@yahoo.com

Received 13 October 2013; Accepted 15 December 2013; Published 20 February 2014

Academic Editors: H. M. Abu-Soud and J. Sastre

Copyright (C) 2014 M. Alamgir Hossain et al. This is an open access article distributed under the Creative Commons Attribution License, which permits unrestricted use, distribution, and reproduction in any medium, provided the original work is properly cited.

\begin{abstract}
Aluminum (Al) sensitive wheat cultivar kalyansona was grown for $14 \mathrm{~d}$ in a range of Ca solution $(125,625$, and $2500 \mu \mathrm{M})$ plus other nutrients without $\mathrm{Al}$. At $14 \mathrm{~d}$ after Ca treatment, half of these plants were harvested (H1), and the rest of the plants were exposed to $100 \mu \mathrm{M}$ Al for additional $6 \mathrm{~d}$ and harvested (H2). Severe Al injury was found only in the plants with the lowest supply of Ca before $\mathrm{Al}$ treatment. Aluminum concentration in the apoplastic fluid was very high at $125 \mu \mathrm{M}$ Ca probably because the plasma membrane of some of the cells was destroyed due to the attack of $100 \mu \mathrm{M}$ Al. Aluminum content in roots decreased with increasing supply of $\mathrm{Ca}$ before $\mathrm{Al}$ treatment. Calcium content decreased drastically at harvest (H2) in the plants with $100 \mu \mathrm{M} \mathrm{Al}$. Under Al stress conditions, the plant responded to $\mathrm{Al}$ in different ways due to not only the different $\mathrm{Ca}$ supply but also the variation of Ca content in the plant tissues. Actually, the plants having the largest $\mathrm{Ca}$ content in the roots before $\mathrm{Al}$ treatment can receive less $\mathrm{Al}$ injury during $\mathrm{Al}$ treatment. To substantiate this idea, a companion study was conducted to investigate the effects of $2500 \mu \mathrm{M}$ Ca supply during, before, and after $100 \mu \mathrm{M} \mathrm{Al}$ treatment on root growth. The results indicated clearly that exogenous Ca supply before $\mathrm{Al}$ treatment is able to alleviate $\mathrm{Al}$ injury but less effective than Ca supply during $\mathrm{Al}$ treatment.
\end{abstract}

\section{Introduction}

The effects of Aluminum on the uptake and accumulation of divalent cations such as $\mathrm{Ca}$ and $\mathrm{Mg}$ have been extensively studied $[1,2]$. It has been accepted that $\mathrm{Al}$ reduces accumulation of divalent cations, especially by displacing $\mathrm{Ca}$ from the cell wall as well as plasma membrane and that higher levels of $\mathrm{Ca}$ in the solution can alleviate deleterious $\mathrm{Al}$ effects [3-6]. Recently, we found that $\mathrm{Al}$ displaced some part of $\mathrm{Ca}$ in cell walls of wheat roots when they were exposed to $\mathrm{Al}$ [7] and additional $\mathrm{Mg}$ was less effective in alleviating $\mathrm{Al}$ injury when exogenous Ca supply was high [8]. The ability to prevent displacement of $\mathrm{Ca}$ in the root apoplast by $\mathrm{Al}$ has been suggested as one of the mechanisms determining $\mathrm{Al}$ tolerance in plants [4]. So, $\mathrm{Al}$ tolerance has been considered to be associated with the ability of absorbing and utilizing $\mathrm{Ca}$ when $\mathrm{Al}$ is present. There have been conflicting reports regarding whether $\mathrm{Ca}$ influx into plant cells is inhibited by Al. The inhibition of Ca uptake in roots by $\mathrm{Al}$ has long been considered a possible cause of toxicity [9], but later reports suggested that the inhibition of root growth is not caused by the reduction of Ca uptake $[10,11]$.

Considerable evidence suggests that the phytotoxic effects of $\mathrm{Al}$ on roots can be partially or completely overcome by increasing the concentration of $\mathrm{Ca}$ in the culture solution $[4,12,13]$. This phenomenon is not solely due to changes in external $\mathrm{Al}$ activity but also related to $\mathrm{Ca}$ nutrition. From reviewing the above-mentioned reports, it is clear that increased supply of $\mathrm{Ca}$ in the culture solution alleviated $\mathrm{Al}$ toxicity by improving Ca status of the plants. Therefore, the status of $\mathrm{Ca}$ of a plant is an important factor to explain the alleviation mechanism/strategies of Al toxicity. Calcium and $\mathrm{Al}$ were applied simultaneously in the culture solution in most of the experiments studying for Al-Ca interactions. 
But literature is very scarce for studying the interactions by applying $\mathrm{Ca}$ before $\mathrm{Al}$ treatment. Therefore, the aim of the present study is to investigate the performance of latter one in alleviating $\mathrm{Al}$ injury. To perform the study objectives, long period pretreatment with $\mathrm{Ca}$ (without $\mathrm{Al}$ ) was done which ensures the high uptake of this element into the plant tissues. That is, a sufficient amount of $\mathrm{Ca}$ accumulation by the plant was accomplished before Al treatment. A companion study was also conducted to investigate the effects of supply of $2500 \mu \mathrm{M}$ Ca during, before, and after $\mathrm{Al}$ treatment on root growth. This study will also clarify the importance of accumulated $\mathrm{Ca}$ in the root tissues during, before, and after $\mathrm{Al}$ treatment in alleviating $\mathrm{Al}$ injury.

\section{Materials and Methods}

2.1. Plant Materials and Growth Conditions. A Bangladeshi wheat (Triticum aestivum L.) cultivar, Kalyansona, was used in our research work. Seeds were sterilized with $1 \%$ $\mathrm{NaClO}$, stirred for $10 \mathrm{~min}$, washed in deionized water, and soaked in distilled water for $24 \mathrm{~h}$. Then the seeds were placed on planting trays with nylon fabric screen for germination in a plastic box containing full nutrient solution $\left(\mathrm{mgL}^{-1}\right): 50 \mathrm{~N}\left(\right.$ as $\left.\mathrm{NH}_{4} \mathrm{NO}_{3}\right), 20 \mathrm{P}\left(\mathrm{Na}_{2} \mathrm{HPO}_{4} \cdot 12 \mathrm{H}_{2} \mathrm{O}\right), 50 \mathrm{~K}$ $\left(\mathrm{K}_{2} \mathrm{SO}_{4}\right), 3 \mathrm{Fe}\left(\mathrm{FeSO}_{4} \cdot 7 \mathrm{H}_{2} \mathrm{O}\right), 0.5 \mathrm{Mn}\left(\mathrm{MnSO}_{4} \cdot 4 \mathrm{H}_{2} \mathrm{O}\right), 0.2 \mathrm{Zn}$ $\left(\mathrm{ZnSO}_{4} \cdot 7 \mathrm{H}_{2} \mathrm{O}\right), \quad 0.5 \mathrm{~B} \quad\left(\mathrm{H}_{3} \mathrm{BO}_{3}\right), 0.05 \mathrm{Cu} \quad\left(\mathrm{CuSO}_{4} \cdot 5 \mathrm{H}_{2} \mathrm{O}\right)$, $0.05 \mathrm{Mo}\left\{\left(\mathrm{NH}_{4}\right)_{6} \mathrm{Mo}_{7} \mathrm{O}_{24} \cdot 4 \mathrm{H}_{2} \mathrm{O}\right\}, 10 \mathrm{Ca}\left(\mathrm{CaCl}_{2} \cdot 2 \mathrm{H}_{2} \mathrm{O}\right)$ and $10 \mathrm{Mg}\left(\mathrm{MgCl}_{2} \cdot 6 \mathrm{H}_{2} \mathrm{O}\right)$, and kept for $7 \mathrm{~d}$ at $\mathrm{pH}$. The seedlings by then had developed 5-7 roots. The seedlings were then transferred to $3.5 \mathrm{~L}$ pots containing 125,625 , and $2500 \mu \mathrm{M}$ $\mathrm{Ca}$ along with other nutrients. The $\mathrm{pH}$ of these treatment solutions was adjusted to 5.0 with $\mathrm{NaOH}$ and $\mathrm{HCl}$, and these solutions were renewed every $3 \mathrm{~d}$. Treatments consisted of three replications and each of them was composed of 3 pots. Each pot had 4 plants. A control plot was set up with $625 \mu \mathrm{M}$ Ca from the beginning. Constant aeration of the nutrient solution was provided. After two weeks, harvest one (H1) was performed with half seedlings, when growth difference appeared (observed visually) due to different levels of $\mathrm{Ca}$. Then the remaining plants were exposed to $100 \mu \mathrm{M} \mathrm{Al}$ containing only $125 \mu \mathrm{M} \mathrm{Ca}$ at $\mathrm{pH} 4.5$ for $6 \mathrm{~d}$. The solutions were renewed every $3 \mathrm{~d}$. Constant aeration to the nutrient solution was also provided. Then harvest two (H2) was performed at $6 \mathrm{~d}$ after $\mathrm{Al}$ treatment. At each harvest, the roots were washed in water and root lengths were measured. Then the roots were used for chemical analyses.

In the companion study, same plant materials and same nutrient solution were used. During Al treatment, other nutrients were not applied except Ca. In this study, $250 \mu \mathrm{M}$ $\mathrm{Ca}$ was considered as low dose and $\mathrm{Ca}$ treatment duration before $\mathrm{Al}$ treatment was reduced to $7 \mathrm{~d}$ instead of $14 \mathrm{~d}$. Three weeks treatment duration was designated by three letters either L $(250 \mu \mathrm{M} \mathrm{Ca})$ or H $(2500 \mu \mathrm{M} \mathrm{Ca})$ consecutively (such as, LLL, HLL, LHL, LLH, and CLLL). C stands for the control (without Al). In the first week, plants were treated with 250 and $2500 \mu \mathrm{M}$ Ca without $\mathrm{Al}$ (before $\mathrm{Al}$ treatment). In the second week, plants were treated with 250 and $2500 \mu \mathrm{M} \mathrm{Ca}$ with $100 \mu \mathrm{M} \mathrm{Al}$ (during Al treatment) but the control was kept without $\mathrm{Al}$. In the third week, plants were treated with 250 and $2500 \mu \mathrm{M}$ Ca without Al (recovery phase). At the end of every week, one-third plants were harvested and root lengths were measured. Here, the harvests were designated as HI, HII, and HIII.

2.2. Determination of $\mathrm{Ca}$ and $\mathrm{Al}$ Contents in Roots. After completion of root growth measurement, the harvested plants (root and shoot) were dried in an oven at $70-800^{\circ} \mathrm{C}$ for $24 \mathrm{~h}$ and dry weights were determined. The $\mathrm{Al}$ content in roots was determined as described [8]. Briefly, $20 \mathrm{mg}$ dry root samples were digested using $10 \mathrm{~N} \mathrm{H}_{2} \mathrm{SO}_{4}$ and $30 \% \mathrm{H}_{2} \mathrm{O}_{2}$. Then $\mathrm{Al}$ in the samples was determined by pyrocatechol violet (PCV) method using a spectrometer [14]. Calcium was determined by atomic absorption spectrophotometry.

2.3. Extraction and Measurements of $\mathrm{Ca}$ and $\mathrm{Al}$ in the Apoplastic Fluid (AF). The method was used as described [15]. After $6 \mathrm{~d}$ exposure to $100 \mu \mathrm{M} \mathrm{Al}$, about $2 \mathrm{~cm}$ (from the apex) long roots were detached from a plant of each treatment, weighed, vacuum-infiltrated with demineralized water, blotted, and reweighed. The infiltrated roots were arranged on strips $(2 \mathrm{~cm} \times 10 \mathrm{~cm})$ of thin polyvinyl sheeting (cut-up of plastic shopping bags). The all cut ends of roots were arranged in the same direction as described [16]. The strips were rolled around to a cylindrical plastic tube with enough pressure to give a tight roll. Then the tube was placed in a $50 \mathrm{~mL}$ plastic syringe with $1.5 \mathrm{~mL}$ Eppendorf cup at its tip. The roots were centrifuged, with their cut ends pointing centrifugally at $440 \mathrm{~g}$ for $15 \mathrm{~min}$ to obtain the AF. Calcium in the AF was measured by atomic absorption spectrometry after digesting the AF with $\mathrm{H}_{2} \mathrm{SO}_{4}-\mathrm{H}_{2} \mathrm{O}_{2}$. Aluminum in the $\mathrm{AF}$ was determined by the same method as described above.

\section{Results}

3.1. Plant Growth. In the absence of $\mathrm{Al}$ (H1), increasing supply of Ca from 125 to $2500 \mu \mathrm{M}$ for $14 \mathrm{~d}$ had adistinct effect on the shoot growth as well as on root growth (Figure 1). The lowest shoot and root dry matter was recorded at $125 \mu \mathrm{M} \mathrm{Ca}$. Similar trend of root dry matter yields was also observed in the companion study at HI (Figure 2). That is, $7 \mathrm{~d}$ culture with $2500 \mu \mathrm{M}$ Ca before Al treatment (HLL) produced 20\% higher root dry matter than the control with $250 \mu \mathrm{M}$ Ca (cLLL). The root dry matter in other plots was similar to the control (Figure 2).

Under $\mathrm{Al}$ stress conditions (H2), the plants with different Ca supply before Al treatment responded to the same level of $\mathrm{Al}$ in different ways (Figure 1). Dry matter production is one of the best indicators of Al toxicity. Severe Al toxicity was found in those plants treated with $125 \mu \mathrm{M}$ Ca before Al treatment. It was the highest (104\%) in the control plot (data not shown). About 34, 46, and 62\% increase in root dry matter was recorded at $\mathrm{H} 2$ in comparison with their corresponding root dry matter at $\mathrm{H} 1$ in the plots pretreated with 125,625 , and $2500 \mu \mathrm{M} \mathrm{Ca}$, respectively. The shoot dry matter production in the presence of $\mathrm{Al}$ was greater than the root dry matter production and showed a similar tendency. 


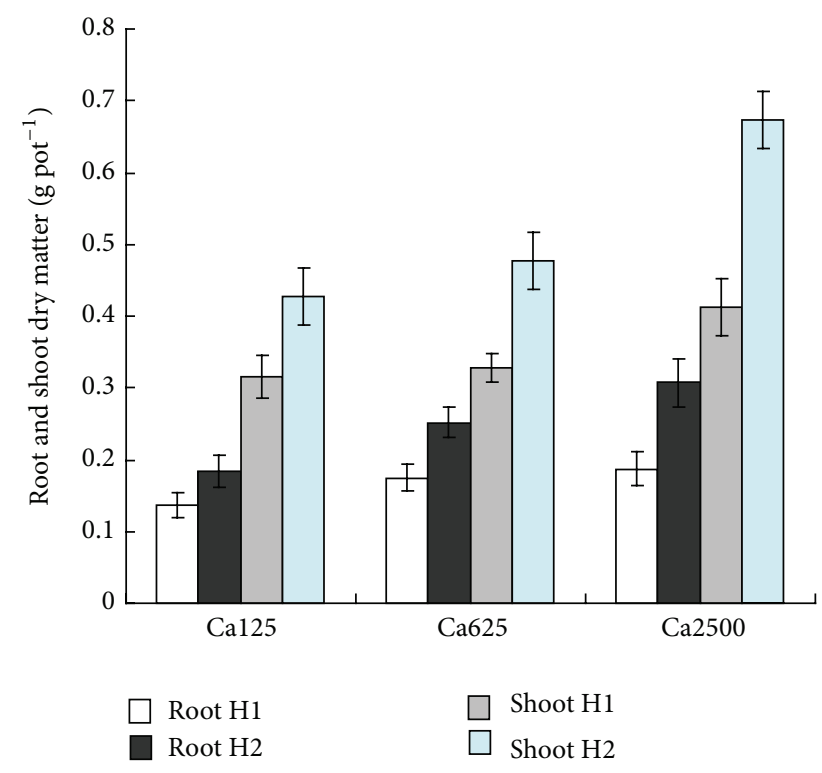

Figure 1: Effects of different levels of Ca supply on root and shoot dry matter of wheat seedlings without $\mathrm{Al}$ at $\mathrm{H} 1$ and with $\mathrm{Al}$ at $\mathrm{H} 2$. After $14 \mathrm{~d}$ of Ca treatment, the seedlings were exposed to $100 \mu \mathrm{M}$ $\mathrm{Al}$ for additional $6 \mathrm{~d}$ for $\mathrm{H} 2$. Values are the means $\pm \mathrm{SE}$ of three replicates.

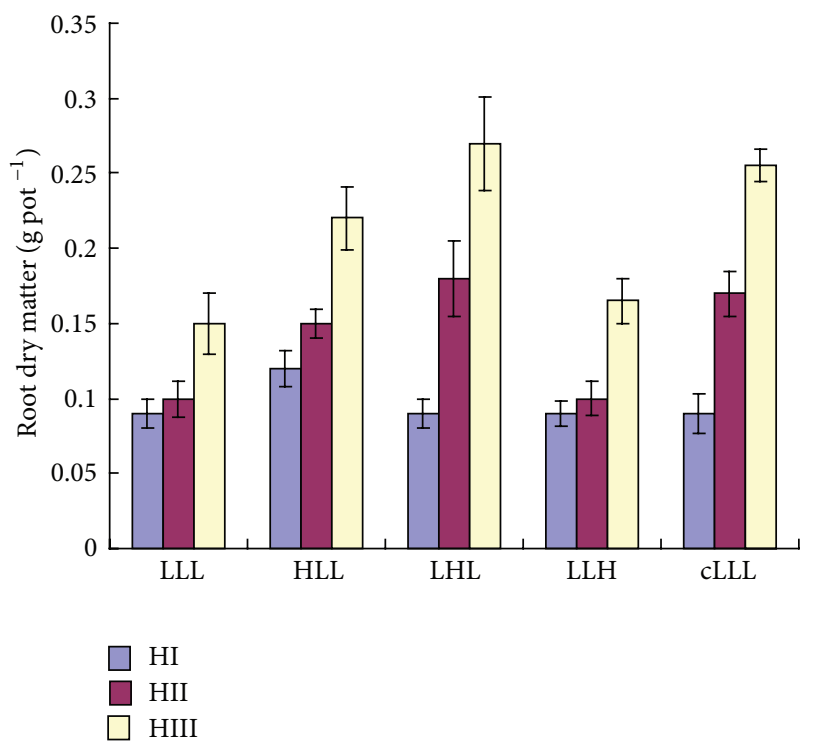

FIGURE 2: Effects of exogenous Ca supply during, before and after $100 \mu \mathrm{M} \mathrm{Al}$ treatment on root growth in wheat plants. Three letters either $\mathrm{L}$ and/or $\mathrm{H}$ indicate three weeks and Ca level $(\mathrm{L}=250 \mu \mathrm{M}$, $\mathrm{H}=2500 \mu \mathrm{M})$. C stands for control. Values are the means $\pm \mathrm{SE}$ of three replicates.

In case of the companion study, $100 \mu \mathrm{M} \mathrm{Al}$ was applied during the second week. After $7 \mathrm{~d}$ exposure to $100 \mu \mathrm{M} \mathrm{Al}$, root dry matter at HII was in the following order: LHL > HLL $>$ LLH $\geq$ LLL (Figure 2). The results also showed that $2500 \mu \mathrm{M}$ Ca supply during $\mathrm{Al}$ treatment was 1.18 times more effective than the Ca supply before $\mathrm{Al}$ treatment in alleviating

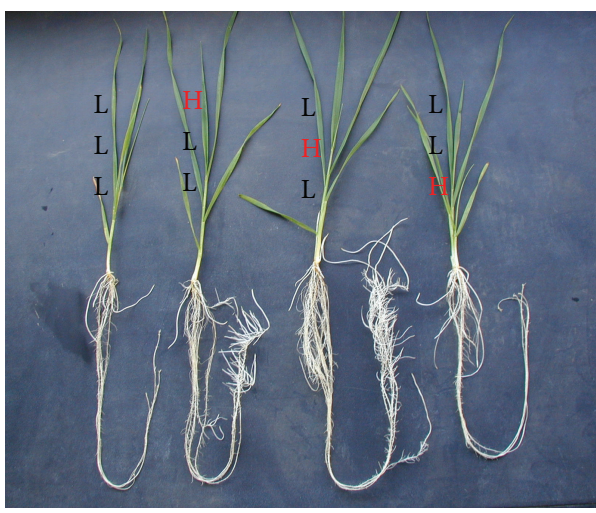

Figure 3: Effects of exogenous Ca supply during, before, and after $100 \mu \mathrm{M} \mathrm{Al}$ treatment on root regrowth in wheat plants at the recovery phase $(7 \mathrm{~d}$ treatment without $\mathrm{Al})$. Three letters either $\mathrm{L}$ and/or $\mathrm{H}$ indicate three weeks and Ca level $(\mathrm{L}=250 \mu \mathrm{M}, \mathrm{H}=$ $2500 \mu \mathrm{M})$.

TABLE 1: Calcium and $\mathrm{Al}$ contents $\left(\mu \mathrm{gg}^{-1}\right.$ dry matter) in the roots obtained before (H1) and after (H2) exposure to $100 \mu \mathrm{M} \mathrm{Al}$ for $6 \mathrm{~d}$. Values are the means \pm SE of three replicates.

\begin{tabular}{lcccc}
\hline \multirow{2}{*}{ Treatments } & \multicolumn{2}{c}{ Ca content } & \multicolumn{2}{c}{ Al content } \\
& H1 & H2 & H1 & H2 \\
\hline Control & $1885 \pm 355$ & $2375 \pm 445$ & ND & ND \\
Ca 125 & $980 \pm 122$ & $95 \pm 12$ & ND & $5791 \pm 825$ \\
Ca 625 & $1885 \pm 355$ & $112 \pm 15$ & ND & $5025 \pm 625$ \\
Ca 2500 & $3010 \pm 585$ & $197 \pm 31$ & ND & $3883 \pm 337$ \\
\hline
\end{tabular}

ND (not detected).

$\mathrm{Al}$ injury. During recovery phase (last week without $\mathrm{Al}$ ), new root development was only observed in LHL and HLL plots (Figure 3). It was also found that new root development capacity was greater in the plants with $2500 \mu \mathrm{M}$ Ca during $\mathrm{Al}$ treatment (LHL) than the plants with the same level of Ca before $\mathrm{Al}$ treatment (HLL). Furthermore, the root tip of the former (LHL) was not strongly affected as observed in HLL. New root development at the root tips was not observed in the plants with $2500 \mu \mathrm{M}$ Ca for $7 \mathrm{~d}$ after Al treatment (LLH). As a consequence at HIII, about $6 \%$ more roots dry matter than the control was observed in LHL, whereas it was $88 \%$ of the control roots dry matter in HLL (Figure 2). The results indicated that high Ca supply during $\mathrm{Al}$ stress recovered $\mathrm{Al}$ injury more quickly than high Ca supply before $\mathrm{Al}$ stress or during recovery phase (without $\mathrm{Al}$ ). However, there was no big difference in root dry matter in those plants with $2500 \mu \mathrm{M}$ $\mathrm{Ca}$ (LLH) and $250 \mu \mathrm{M} \mathrm{Ca}$ (LLL) during the recovery phase, although more new roots were observed at the base of shoots in LLH than LLL (Figure 3).

3.2. $\mathrm{Ca}$ and $\mathrm{Al}$ Contents in Roots. In the absence of $\mathrm{Al}(\mathrm{H1})$, $\mathrm{Ca}$ content in the roots increased with increasing supply of $\mathrm{Ca}$ in the culture solution (Table 1). The highest Ca content was recorded in the roots with $2500 \mu \mathrm{M}$ Ca for $14 \mathrm{~d}$ before $\mathrm{Al}$ treatment. Calcium content in roots decreased drastically in the presence of $\mathrm{Al}(\mathrm{H} 2)$. The plants with the highest 
TABLE 2: Calcium and $\mathrm{Al}$ contents ( $\mu \mathrm{gg}^{-1}$ dry matter) in the roots obtained before (HI), during (HII), and after (HIII) exposure to $100 \mu \mathrm{M} \mathrm{Al}$ for $7 \mathrm{~d}$. Values are the means \pm SE of three replicates.

\begin{tabular}{|c|c|c|c|c|c|c|}
\hline \multirow{2}{*}{$\#$} & \multicolumn{2}{|c|}{$\mathrm{HI}$} & \multicolumn{2}{|c|}{ HII } & \multicolumn{2}{|c|}{ HIII } \\
\hline & $\mathrm{Ca}$ & $\mathrm{Al}$ & $\mathrm{Ca}$ & $\mathrm{Al}$ & $\mathrm{Ca}$ & $\mathrm{Al}$ \\
\hline LLL & $927 \pm 35$ & ND & $127 \pm 16$ & $5134 \pm 387$ & $159 \pm 22$ & $4325 \pm 503$ \\
\hline HLL & $2915 \pm 275$ & ND & $305 \pm 22$ & $3883 \pm 122$ & $387 \pm 51$ & $2552 \pm 202$ \\
\hline LHL & $927 \pm 27$ & ND & $515 \pm 31$ & $3415 \pm 272$ & $649 \pm 105$ & $2347 \pm 131$ \\
\hline LLH & $935 \pm 25$ & ND & $132 \pm 12$ & $5101 \pm 402$ & $193 \pm 21$ & $4061 \pm 263$ \\
\hline cLLL & $942 \pm 23$ & ND & $1245 \pm 98$ & ND & $1727 \pm 235$ & ND \\
\hline
\end{tabular}

${ }^{\#}$ Treatment condition: 3 letters indicate 3 weeks. c stands for control. $\mathrm{L}=250 \mu \mathrm{M} \mathrm{Ca}$. $\mathrm{H}=2500 \mu \mathrm{M} \mathrm{Ca}$, and ND: not detected.

$\mathrm{Ca}\left(3010 \mu \mathrm{gg}^{-1} \mathrm{DM}\right)$ content at $\mathrm{H} 1$ showed a remarkable reduction in $\mathrm{Ca}\left(197 \mu \mathrm{gg}^{-1} \mathrm{DM}\right)$ content after $6 \mathrm{~d}$ exposure to $100 \mu \mathrm{M} \mathrm{Al}$. Aluminum was undetected in the plant at $\mathrm{H} 1$ and the control plant at $\mathrm{H} 2$. The plants pretreated with different levels of $\mathrm{Ca}$ had different $\mathrm{Al}$ content in the roots at $\mathrm{H} 2$. The highest $\mathrm{Al}$ content was determined in the roots with the lowest Ca supply before $\mathrm{Al}$ treatment. Aluminum content decreased gradually with increasing supply of $\mathrm{Ca}$ before $\mathrm{Al}$ treatment.

In the companion study, $\mathrm{Ca}$ content in the roots varied with the supply of $\mathrm{Ca}$ for $7 \mathrm{~d}$ before $\mathrm{Al}$ treatment (Table 2). Actually, Ca supply in LLL, LHL, LLH, and cLLL treatments was same during first week. Therefore, Ca content among the treatments was identical at $\mathrm{HI}$. In the second week (during $\mathrm{Al}$ treatment), the lowest Ca content was observed in LLL and LLH. The Ca content in roots decreased drastically (about $90 \%)$ in the presence of $\mathrm{Al}$ (HII) in the plants pretreated with $2500 \mu \mathrm{M} \mathrm{Ca}$ (HLL), whereas it was $44 \%$ in the plants that treated with $2500 \mu \mathrm{M} \mathrm{Ca}$ (LHL) during $\mathrm{Al}$ exposure. In the control plants (cLLL), Ca uptake increased by $33 \%$ during second week treatment without Al. During recovery phase (HIII), Ca content increases in all treatments and the highest was in LHL. The highest Al content at HII was observed in LLL and LLH. It was 1.5 and 1.4 times higher than LHL and HLL, respectively. The results further showed that the difference in Al content between LHL and HLL was lesser extent than the difference observed in their root dry matter yields (Figure 2). Again, $\mathrm{Al}$ content at the recovery phase (HIII) was lower than the values observed during $\mathrm{Al}$ treatment (HII), although the trend was similar to the harvest two (HII).

3.3. $\mathrm{Ca}$ and Al Concentrations in the Apoplastic Fluid (AF). Calcium concentration in the $\mathrm{AF}$ at $125 \mu \mathrm{M} \mathrm{Ca}$ was larger than that of at $625 \mu \mathrm{M} \mathrm{Ca}$ (Table 3). The highest Ca concentration in the AF was recorded at $2500 \mu \mathrm{M} \mathrm{Ca}$. Aluminum concentration in the $\mathrm{AF}$ of roots at $\mathrm{H} 2$ decreased with increasing supply of $\mathrm{Ca}$ before $\mathrm{Al}$ treatment. Aluminum concentration in the AF of the roots was reduced by 4 times, when these plants were pretreated with Ca supply from 125 to $2500 \mu \mathrm{M}$.
TABLE 3: Calcium and Al concentrations in the apoplastic fluid of the roots treated with $100 \mu \mathrm{M} \mathrm{Al}$ for $6 \mathrm{~d}(\mathrm{H} 2)$. The wheat seedlings were pretreated with different levels of $\mathrm{Ca}$ for $14 \mathrm{~d}$ before $\mathrm{Al}$ treatment. Values are means \pm SE of three replicates.

\begin{tabular}{lcc}
\hline Treatments $(\mu \mathrm{M})$ & \multicolumn{2}{c}{ Concentrations $\mu \mathrm{gL}^{-1} \mathrm{AF}$} \\
& $\mathrm{Ca}$ & $\mathrm{Al}$ \\
\hline Ca 125 & $6.5 \pm 0.28$ & $1.15 \pm 0.10$ \\
Ca 625 & $5.0 \pm 0.57$ & $0.35 \pm 0.07$ \\
Ca 2500 & $12.5 \pm 0.50$ & $0.28 \pm 0.05$ \\
\hline
\end{tabular}

\section{Discussion}

In the absence of $\mathrm{Al}$, there were differences among the $\mathrm{Ca}$ levels in terms of plant (root + shoot) growth (Figures 1 and 2) and Ca nutrition (Tables 1 and 2). Under Al stress conditions (H2), root dry matter production occurred substantially but differentially among the $\mathrm{Ca}$ treatments in the presence of $\mathrm{Al}$ for $6 \mathrm{~d}$ (Figure 1). The differential growth may be the residual effect of accumulated $\mathrm{Ca}$ in the plant tissues. That is, long period pretreatment with high Ca supply before $\mathrm{Al}$ treatment resulted in enrichment of Ca status of the seedlings (Table 1), prevented the $\mathrm{Al}$ accumulation (Table 1 ) in root tissues, and subsequently increased dry matter production (Figure 1). Although the tested cultivar, Kalyansona, is sensitive to $\mathrm{Al}$ [7], cultivation with $100 \mu \mathrm{M} \mathrm{Al}$ for $6 \mathrm{~d}$ caused a decrease in root elongation by only $44 \%$ at $125 \mu \mathrm{M}$ Ca while it was $56 \%$ within $48 \mathrm{~h}$ for $4 \mathrm{~d}$ old seedlings (data not shown). Therefore, other factors such as plant age may cause the difference in the short-term and long-term experiments as reported [5].

Severe $\mathrm{Al}$ injury was found in the plants that pretreated with $125 \mu \mathrm{M} \mathrm{Ca}$ (Figure 1). It is assumed that all of the common binding sites (CBS) of the roots of these plants are not occupied by Ca during pretreatment period. Many of the CBS remain exposed as reported in our previous study [17]. During $\mathrm{Al}$ treatment, both the $\mathrm{Ca}^{2+}$ bounded and unbounded binding sites in the cell wall as well as plasma membrane may be occupied by $\mathrm{Al}$ since $\mathrm{Al}^{3+}$ has stronger affinity to the negative $\mathrm{CBS}$ than $\mathrm{Ca}^{2+}$. Such binding of $\mathrm{Al}^{3+}$ to the cell wall as well as plasma membrane caused the destruction of epidermal and cortical cells in the root tip, elongating 
zones, and proximal parts of the root metabolically and morphologically $[18,19]$. This type of destruction of root cellsincreases total $\mathrm{Al}$ content in addition to the $\mathrm{Al}$ content accomplished by the intact root before destruction. In addition, Al caused disintegration of plasma membrane in barley root cells [20]. In our present study, the plasma membrane in some of the root cells was destroyed due to the attack of $100 \mu \mathrm{M} \mathrm{Al}$ for $6 \mathrm{~d}$ in the presence of only $125 \mu \mathrm{M} \mathrm{Ca}$, and $\mathrm{Al}$ in these cells was possibly extracted during extraction of AF. Therefore, Al concentration in the AF may be affected. Calcium concentration in the $\mathrm{AF}$ at $125 \mu \mathrm{M}$ Ca was larger than that of at $625 \mu \mathrm{M}$ Ca (Table 3). Severe attack of Al was accomplished in the former (Figure 1) which possibly caused the destruction of plasma membrane of many/more cells than the latter and consequently affected apoplastic $\mathrm{Ca}$ concentration. The highest supply of $\mathrm{Ca}(2500 \mu \mathrm{M})$ before $\mathrm{Al}$ treatmentnot only enable the $\mathrm{Ca}^{2+}$ ions to occupy most of the CBS of the roots [21] but also enable them present in the highest concentration in the apoplast (Table 3). According to toxicant-ameliorant competition for CBS [4], bounded $\mathrm{Ca}$ along with large amount of unbounded $\mathrm{Ca}$ in the apoplast may protect the metabolical and morphological disruption of cell wall and plasma membrane [17] in the presence of Al. This protection effect is clearly reflected on the results of low content of $\mathrm{Al}$ in the roots (Table 1) as well as low concentration of $\mathrm{Al}$ in the $\mathrm{AF}$ (Table 3 ) and increased root dry matter production (Figure 1).

The disturbance of $\mathrm{Ca}$ homeostasis via $\mathrm{Ca}$ displacement from CBS and increased cytosolic Ca level by Al is a wellestablished event during Al-Ca interactions in plants [20]. In our present study, the plants with high Ca supply showed a remarkable reduction in the Ca content in roots after $6 \mathrm{~d}$ exposure to $\mathrm{Al}$ (Table 1 ). This remarkable reduction in the Ca content may be caused not only by displacing $\mathrm{Ca}$ from the CBS as observed in the previous studies $[4,8]$ but also by the expense of $\mathrm{Ca}$ in the cells for continuation of root growth during $\mathrm{Al}$ stress (Figure 1). Shoot dry matter was also increased after Al treatment (Figure 1). The results can be explained by the expense of both shoot containing $\mathrm{Ca}$ and translocated $\mathrm{Ca}$ from roots since $\mathrm{Al}$ decreased $\mathrm{Ca}$ content in the roots (Table 1).

In the companion study, the highest root growth at HII (Figure 2) as well as the highest Ca content (Table 2) was observed when $2500 \mu \mathrm{M}$ Ca was supplied during $\mathrm{Al}$ treatment. The results also showed that $2500 \mu \mathrm{M}$ Ca supply before $\mathrm{Al}$ treatment is able to alleviate $\mathrm{Al}$ injury but lesser extent than the same level Ca supply during Al treatment (Figure 2). The difference of Ca content between LHL and HLL (Table 2) showed the similar trend to the difference of root dry matter yields (Figure 2). Therefore, it can be speculated that accumulated $\mathrm{Ca}$ of the wheat plants plays an important role to alleviate $\mathrm{Al}$ injury (expressed by root dry matter yields) during $\mathrm{Al}$ treatment. But $2500 \mu \mathrm{M} \mathrm{Ca}$ supply (LLH) at the recovery phase could not improve root growth inhibition caused by Al toxicity (Figure 2), and new root development at the root tips was not observed in this plot (Figure 3). This may be the result of destruction of the roots tips having meristematic tissues during $\mathrm{Al}$ treatment.
However, new root initiation at the base of shoots in LLH (Figure 3) indicates the recovery from $\mathrm{Al}$ injury due to high Ca supply in culture solution. The plants in LLH may recover much faster from $\mathrm{Al}$ injury than those in LLL. In conclusion, pretreatment with high doses of calcium on the injury induced by aluminum in wheat plants, especially in roots, may be beneficial to protect against subsequent aggression by aluminum. Although the interaction between $\mathrm{Ca}$ and $\mathrm{Al}$ has been already extensively studied, the potential benefit of $\mathrm{Ca}$ pretreatment may be of interest to the field.

\section{Conflict of Interests}

The authors declare that there is no conflict of interests regarding the publication of this paper.

\section{References}

[1] D. L. Goldbold, "Aluminum decreases root growth and calcium and magnesium uptake in Picea abies seedlings," in Plant-Soil Interaction at Low PH, R. J. Wright, V. C. Baligar, and R. P. Murrmann, Eds., pp. 747-753, Kluwer Academic, Dordrecht, The Netherlands, 1991.

[2] G. J. Taylor, "The physiology of aluminum phytotoxicity" in Metal Ions in Biological Systems. Aluminum and Its Role in Biology, H. Sigel, Ed., vol. 24, pp. 123-163, Marcel Dekker, New York, NY, USA, 1988.

[3] W. G. Keltjens and K. Tan, "Interactions between aluminium, magnesium and calcium with different monocotyledonous and dicotyledonous plant species," Plant and Soil, vol. 155-156, no. 1, pp. 485-488, 1993.

[4] T. B. Kinraide, "Three mechanisms for the calcium alleviation of mineral toxicities," Plant Physiology, vol. 118, no. 2, pp. 513-520, 1998.

[5] Z. Rengel, "Role of calcium in aluminum toxicity," New Phytologist, vol. 121, pp. 499-513, 1992.

[6] R. E. Wilkinson and R. R. Duncan, "Calcium $\left({ }^{45} \mathrm{Ca}^{2+}\right)$ absorption by sorghum seedling root tips in the presence of ruthenium red and verapamil," Journal of Plant Nutrition, vol. 16, no. 10, pp. 1969-1973, 1993.

[7] A. K. M. Z. Hossain, M. A. Hossain, H. Koyama, and T. Hara, "Effects of aluminum and boron supply on growth of seedlings among 15 cultivars of wheat (Triticum aestivum L.) grown in Bangladesh," Soil Science and Plant Nutrition, vol. 50, no. 2, pp. 189-195, 2004.

[8] M. A. Hossain, K. Ban, A. K. M. Z. Hossain, H. Koyama, and T. Hara, "Combined effects of Mg and Ca supply on alleviation of Al toxicity in wheat plants," Soil Science and Plant Nutrition, vol. 50, no. 2, pp. 283-286, 2004.

[9] J. W. Huang, D. L. Grunes, and L. V. Kochian, "Aluminum effects on the kinetics of calcium uptake into cells of the wheat root apex-quantification of calcium fluxes using a calcium-selective vibrating microelectrode," Planta, vol. 188, no. 3, pp. 414-421, 1992.

[10] D. L. Jones, L. V. Kochian, and S. Gilroy, "Aluminum induces a decrease in cytosolic calcium concentration in BY-2 tobacco cell cultures," Plant Physiology, vol. 116, no. 1, pp. 81-89, 1998.

[11] P. R. Ryan, T. B. Kinraide, and L. V. Kochian, " $\mathrm{Al}^{3+}-\mathrm{Ca}^{2+}$ interactions in aluminum rhizotoxicity. I. Inhibition of root growth is not caused by reduction of calcium uptake," Planta, vol. 192, no. 1, pp. 98-103, 1994. 
[12] C. D. Foy, R. L. Chaney, and M. C. White, "The physiology of metal toxicity in plants," Annual Review of Plant Physiology, vol. 29, pp. 511-566, 1978.

[13] T. B. Kinraide and D. R. Parker, "Cation amelioration of aluminum toxicity in wheat," Plant Physiology, vol. 83, pp. 546$551,1987$.

[14] G. L. Kerven, D. G. Edwards, C. J. Asher, P. S. Hallman, and S. Kokot, "Aluminium determination in soil solution. II. Shortterm colorimetric procedures for the measurement of inorganic monomeric aluminium in the presence of organic acid ligands," Australian Journal of Soil Research, vol. 27, no. 1, pp. 91-102, 1989.

[15] S. Seling, A. H. Wissemeier, P. Cambier, and P. Van Cutsem, "Calcium deficiency in potato (Solanum tuberosum ssp. tuberosum) leaves and its effects on the pectic composition of the apoplastic fluid," Physiologia Plantarum, vol. 109, no. 1, pp. 4450, 2000.

[16] R. Rohringer, F. Ebrahim-nesbat, and G. Wolf, "Proteins in intercellular washing fluids from leaves of barley (Hordeum vulgare L.)," Journal of Experimental Botany, vol. 34, no. 12, pp. 1589-1605, 1983.

[17] M. A. Hossain, A. K. M. Z. Hossain, T. Kihara, H. Koyama, and T. Hara, "Aluminum-induced lipid peroxidation and lignin deposition are associated with an increase in $\mathrm{H}_{2} \mathrm{O}_{2}$ generation in wheat seedlings," Soil Science and Plant Nutrition, vol. 51, no. 2, pp. 223-230, 2005.

[18] C. Hecht-Buchholz and J. Schuster, "Responses of Al-tolerant Dayton and Al-sensitive Kearney barley cultivars to calcium and magnesium during al stress," Plant and Soil, vol. 99, no. 1, pp. 47-61, 1987.

[19] T. Wagatsuma, M. Kaneko, and Y. Hayasaka, "Destruction process of plant root cells by aluminum," Soil Science \& Plant Nutrition, vol. 33, pp. 161-175, 1987.

[20] J.-W. Pan, M.-Y. Zhu, and H. Chen, "Aluminum-induced cell death in root-tip cells of barley," Environmental and Experimental Botany, vol. 46, no. 1, pp. 71-79, 2001.

[21] P. Bhuja, K. McLachlan, J. Stephens, and G. Taylor, "Accumulation of 1,3- $\beta$-D-glucans, in response to aluminum and cytosolic calcium in Triticum aestivum," Plant and Cell Physiology, vol. 45, no. 5, pp. 543-549, 2004. 

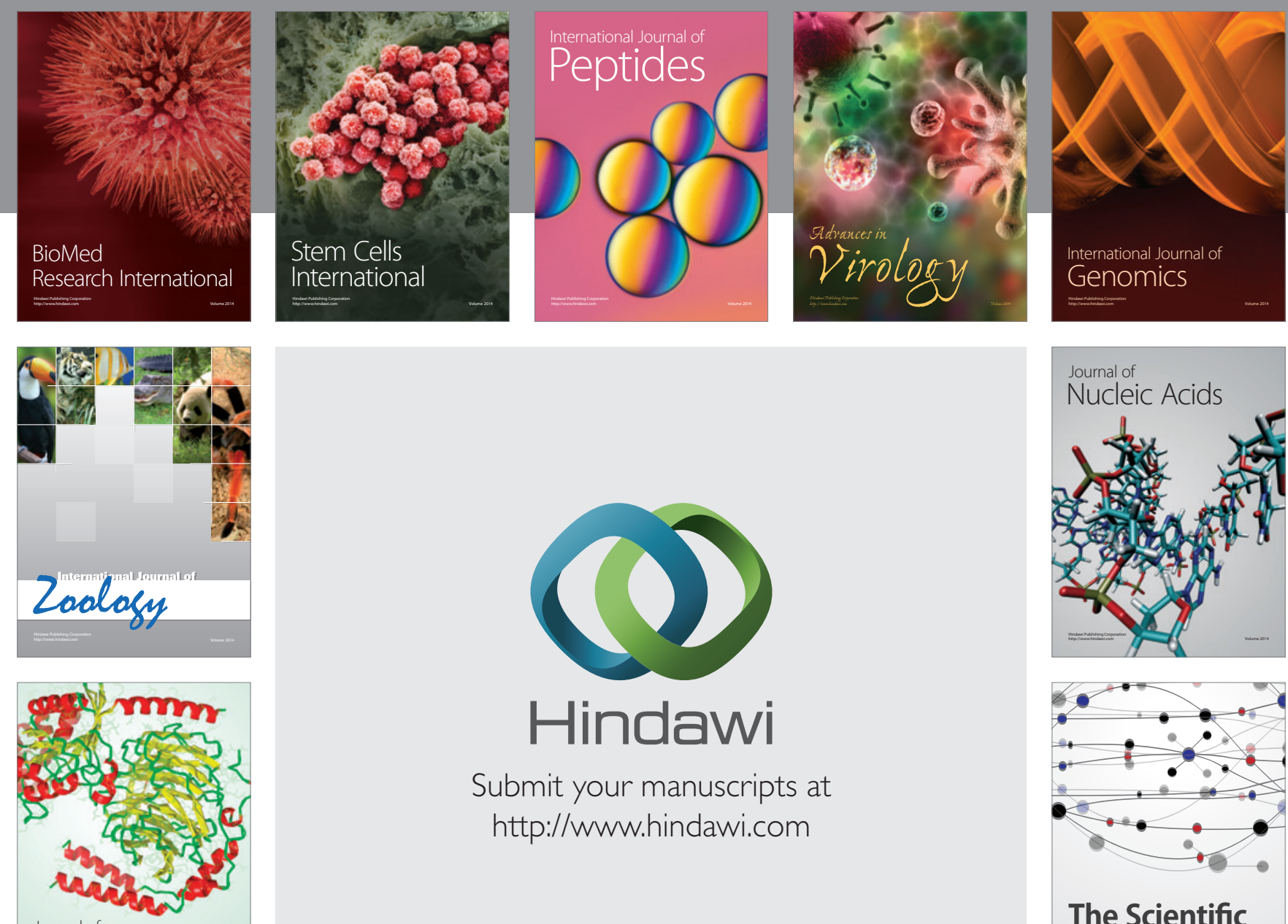

Submit your manuscripts at

http://www.hindawi.com

Journal of
Signal Transduction
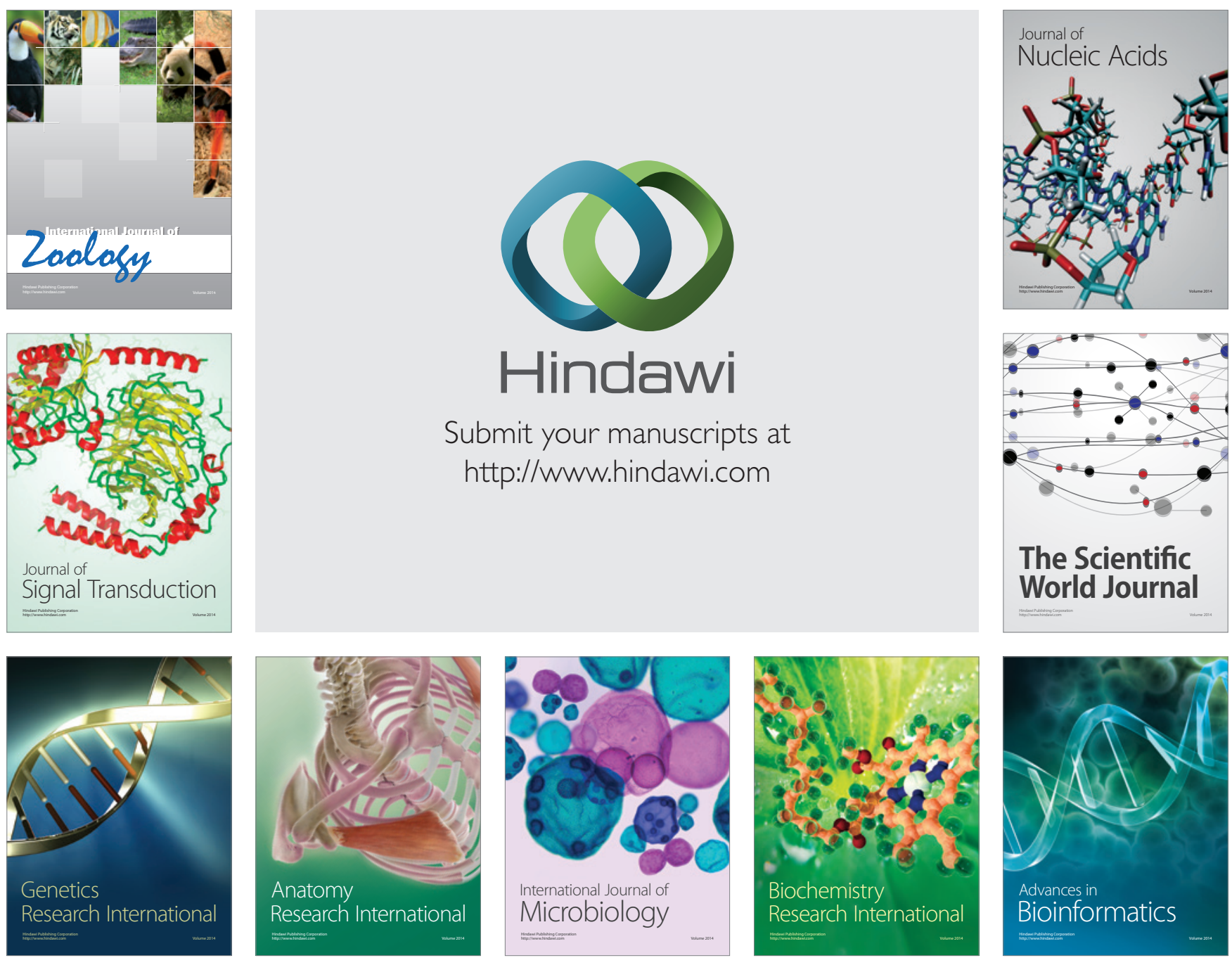

The Scientific World Journal
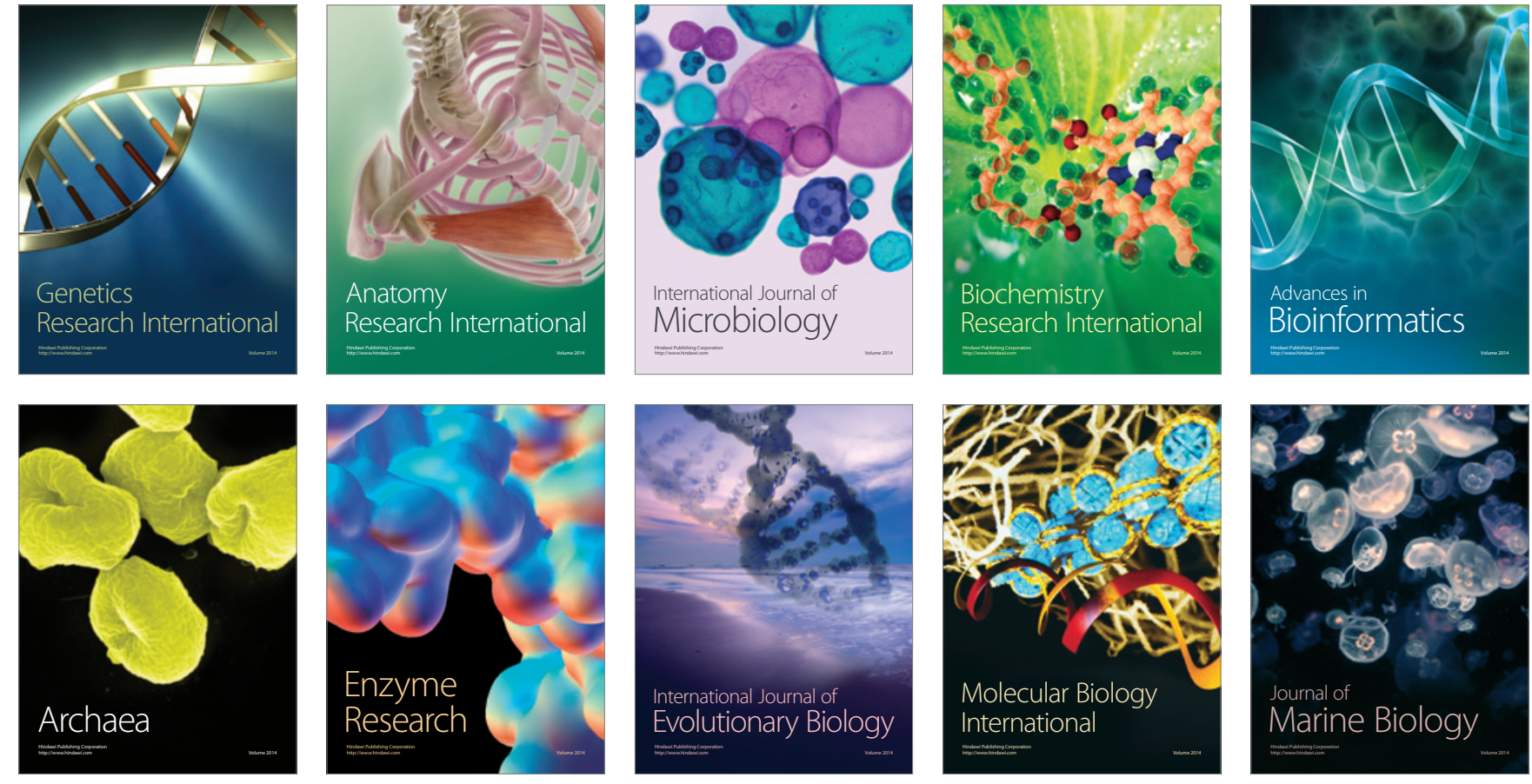